Marquette University

e-Publications@Marquette

Social and Cultural Sciences Faculty Research and

Publications

Social and Cultural Sciences, Department of

$11-1-2008$

There Is No Place Like Home: The Body as the Scene of the Crime in Sexual Assault Intervention

Sameena A. Mulla

Marquette University, sameena.mulla@marquette.edu

Accepted version. Home Cultures, Vol. 5, No. 3 (November 2008): 301-325. DOI. (C) 2008 Berg. Used with permission. 


\title{
There is No Place Like Home: The Body as the Scene of the Crime in Sexual Assault Intervention ${ }^{1}$
}

\author{
Sameena Mulla \\ Department of Sociology, Marquette University \\ Milwaukee, WI
}

\begin{abstract}
The body is the scene of the crime," is an oft-repeated phrase among nurses conducting sexual assault forensic examinations. This instruction reminds nurses that the object under scrutiny, the sexually violated body, is the location and source of establishing legal evidence. The nurses' interest lies in recovering evidentiary materials towards deriving a future juridical truth and providing a means for remedy or restitution. The constitution of truth obscures how the subject comes to be at home and dwell in a world where rape occurs. This article argues that regarding the body as a crime scene is more than a rhetorical or pedagogical move made by forensic practitioners. Rather, forensic examination is constituted through rigorous and meticulous techniques (of evidence collection and observation) that scrutinize the body of the sexually violated subject in such a way that the harming and healing capacities of the domestic are disarticulated from one another. What is at stake is the state's reliance on a notion of the domestic as a sphere to which one might return and heal, even in instances where the domestic itself is the source or site of injury, such as incest and domestic violence. By drawing on cases observed in the emergency room over a forty-two-month period, I argue the scopic regime of forensic examination operates to diminish the state's knowledge of its inability to remedy every situation, while continuing to move forward with the work of healing.
\end{abstract}

Keywords: sexual assault, documentary practices, forensic examination, legal technology

This article examines the ways in which home and the sexually violated bodies within particular homes are configured and administratively rendered by the state. In the USA, institutional imaginaries of sexual violence are configured as "medico-legal;" the 
term highlights the simultaneously distinct and conjoined therapeutic and juridical aims of intervention. Forensic training manuals, textbooks, and policy documents routinely frame sexual assault interventions as such (Crowley 1999, Office on Violence Against Women 2004, Olshaker et al. 2006). To restore juridical and medical order, intervention participants must have a working definition of the nature of the rupture they aim to correct. In recent years, the intervention has focused on the disruption of relationships of care, intimacy, and trust. Violence between intimates, acquaintances, and "friends" is seen to be particularly destructive, and these distinctions carry over into the formalization of "stranger" and "acquaintance" categories by law enforcement personnel (Estrich 1988: 4-8). ${ }^{2} \mathrm{~A}$ recent study of sex offenses in the USA determined that eight out of ten rapes were acquaintance rapes (Tjaden and Thoennes 2006: 21). The term "acquaintance" encompasses various types of relationships and degrees of intimacy. Crime scenes, too, can fall into categories of strange or familiar. While formal distinctions apply to the perpetrator of rape, there are no official distinctions for sites of sexual assaults. ${ }^{3}$ Sexual assault victims, however, convey a sense of place in their disclosures of the event. "Home" is often the location in question.

In the hospital emergency room victims riddle their disclosures of sexual violence with descriptions, stories, objects or familiar/familial figures of and from home. The sexually violated body is the object of forensic scrutiny; a rigorous and meticulous technique of evidence collection accounts for the spaces and things surrounding the body and littering the domestic crime scene. In this article, I argue that in cases of sexual violence located in the victims' home, forensic techniques allow the "scene of the crime" to shift from the home to the body and create the conditions of possibility for the emergence of a domestic that has (at least) two different characters. I use the term "domestic" to refer to a set of norms defining kinship, care, and intimacy, while "home" is the predominant form for expressing domestic norms in the locality in which I conducted research. ${ }^{4}$ The first face of the domestic is as the source of violence and vulnerability. This "dangerous" domestic unfolds alongside a second aspect, that of the domestic as the place in which one returns to everyday life (Das 2006). The intervention imbues home with the capacity to heal; hospital discharge instructions name it the ideal site of return. Within a forensic scopic regime, ${ }^{5}$ the contemporaneous features of the domestic are disarticulated from one

Home Cultures, Vol. 5, No. 3 (November 2008): pg. 301-325. DOI. This article is (C) Bloomsbury Publishing and permission has been granted for this version to appear in e-Publications@Marquette. Bloomsbury Publishing does not grant permission for this article to be further copied/distributed or hosted elsewhere without the express permission from Bloomsbury Publishing. 
another and enshrined within institutional protocols and documentary practices. It is within the forensic documentary archive that the dangerous and healing qualities of the domestic are constituted as related but discrete. As institutional protocols disarticulate the two domestics, personnel are able to meet both juridical and therapeutic ends, imagined as separate.

This article draws on research conducted in a hospital-based forensic nursing program from January 2002 through December 2005. Underreporting leads to difficulty in discerning the rates and frequency of sexual assault in the USA, though figures hover in the region of one in every seven or eight women experiencing rape (Tjaden and Thoennes 2006). The Tjaden and Thoennes study also finds that about $3 \%$ of American men are sexually victimized in their life times, and that men are much less likely to report their experiences than women (Brochman 1991). The hospital in which I conducted my research served both male and female victims. ${ }^{6}$ During the early phase of the project, I was both a researcher and on-call patient advocate in the emergency room. ${ }^{7}$ I observed forty-four forensic examinations using this method and was never asked to leave the hospital upon disclosure of my role as an anthropological researcher. My field notes were written daily, immediately following my exit from the hospital. I subsequently returned to the notes, and elaborated the details in them. In the second phase of the research period, I suspended all patient advocacy activity and observed forensic nurses at their administrative and training duties. The evidence I present is based on these two research phases.

\section{Statistical and Categorical Imaginaries of Crime in the Home}

The location of about a quarter of incidents of violent crime was at or near the victim's home. Among common locales for violent crimes were on streets other than those near the victim's home $(19 \%)$, at school $(12 \%)$, or at a commercial establishment $(8 \%)$.

For violent crime, about half occurred within a mile from home and $76 \%$ within five miles. Only $4 \%$ of victims of violent crime reported that the crime took place more than fifty miles from their home. 
About seven in ten female rape or sexual assault victims stated the offender was an intimate, other relative, a friend or an acquaintance (US Bureau of Justice Statistics 2005).

The existence of aggregated statistical data on crime and injury at or near home indicates a view of home as an object regarded by the state over a long period of time. Heeding these statistics as an accurate picture of the geography of harm in the USA would lead one to regard the home with trepidation and caution. ${ }^{8}$ According to the Bureau of Justice Statistics, it is in or near home that an individual is most likely to be hurt, killed, or otherwise subject to violence. The most likely perpetrators, moreover, are relatives, friends, and acquaintances. These patterns of crime incidence may also apply to political violence. Many historical and anthropological studies reveal that in some cases, home is a common site of politically motivated killing, torture, and abduction (see, for just a few examples, Das et al. 2001 , or Roth and Salas 2001), although in these cases, the source of violence may likely come from outside the home. ${ }^{9}$ While violence does befall many in unfamiliar places at the hands of unfamiliar people, anthropologists, historians, criminologists, and statisticians hold that these remain the least likely character of incidents of harm.

Although popular imaginaries regard and construct home as a location of intimacy and stability (e.g. McKeon 2005), ${ }^{10}$ the indexing of a range of behaviors and events within continually evolving discourses of "home invasion" (Nielsen 2005) or "domestic violence" (Fineman and Mykitiuk 1994) demonstrate the institutionalization of statistical patterns of harm in or near the home. With regard to its incidence, sexual violence shares some features of these same patterns. Intimacy and cohabitation carry grave risks acknowledged through the invention or persistence of such classifications as incest (R. Porter and Teich 1994) and marital rape (Russell 1990[1982]). ${ }^{11}$

In their research on post-sexual assault examination practice in Canada, Parnis and Du Mont found that, "while corroborating evidence may be gathered from a number of sources, including the scene of the offence, the suspect, and witnesses, great emphasis has been placed on that which is obtained from the body of the woman who has been assaulted" (2002: 847). In the course of the many classes, orientations, and presentations I observed, Baltimore, Maryland, forensic nurse examiners echoed the emphasis, often repeating the 
phrase, "the body is the scene of the crime." The conceptual frame of the "scene" connotes both a theatrical and temporal perspective. Smock notes that "the word 'scene'" suggests something spectacular while lending itself "to evoking what 'happens' in the interim, in that at least it allows one not to speak as though of something taking place in time" [sic] (Smock 1986: xi).12 "The body is the scene of the crime" is a phrase reiterated for the benefit of nurse examiners, police detectives, patient advocates, state's attorneys, and grand juries. ${ }^{13}$ Asking Emma, one of the senior forensic nurse examiners with whom I had worked for over two years, to unpack the meaning of this expression lead to the following exchange during the course of one of our interviews:

EMMA: My job as a forensic nurse is to treat the victim and her clothing as a crime scene. My job is to collect any type of trace evidence, any type of bodily fluids, anything I can of the alleged perpetrator. I am the DNA collector.

ME: So you document the crime scene?

EMMA: Yes, which is her, and her clothing. So hopefully I will recover the perpetrator's DNA from her clothing or from the outside of her body or from the inside of her body. Of course years ago there was no such thing. DNA technology has absolutely exploded. And it amazes me what's going on now, and it's going to be truly amazing what's going to be in ten years. It's going to be very science fiction-like. It is.

Emma responds to my query about the description of a rape victim's body as a crime scene by patiently telling me that the victim and her clothing hold and therefore can be searched for trace evidence, bodily fluid, and DNA. The effort to recover the perpetrator's DNA includes searching both the inside and outside of the victim's body. Emma's equation of the victim's body to the crime scene is quickly followed upon by a remark of appreciation and wonderment over the technological advances of forensic science. For her, the victim's body opens out onto a world of genetic sequencing and DNA fingerprinting that will soon approach the "science fiction-like." The role of forensic technology in constituting its own scopic regime begins to emerge through Emma's exclamation of pleasure and curiosity in potential techno-scientific developments. 
NOT THE PUBLISHED VERSION; this is the author's final, peer-reviewed manuscript. The published version may be accessed by following the link in the citation at the bottom of the page.

As Forth and Crozier (2005: 1) describe, disturbed domestic tranquility can be "rewritten" or displaced onto the body. ${ }^{14}$ If the body is the scene of the crime, what happens to the other (geographic) scene of the crime? What happens to the accounts of domestic violence, child abuse, and acquaintance rape frequently related by rape victims? It is not simply Emma's description that disassociates the body of the rape victim from a place or setting. Forensic intervention itself draws the nurse examiner into the minutiae of bodily examination while an investigator from the Maryland Crime Lab will attend to the crime scene. Though they are disaggregated at the point of forensic intervention, the evidence will be reunited in the legal case. This division of labor leads nurse examiners to encounter the home in the two aforementioned domestic registers of risk and healing: the first as trace evidence on the body of the victim, and the second as the place to which victims are commended for follow-up care. Thus, victims are routinely discharged from the emergency room to their homes, even if the home is the reported site of the sexual violence currently under investigation. While forensic examination may require a somewhat narrow optic, its practice within the field of nursing raises questions as to how harm and healing are so closely sutured together within the domestic. I now turn to Keisha, Laura, and Leda, three women whose cases I observed in the emergency room. The harm of the domestic is not a distant and shadowy world that glides imperceptibly beneath the narratives of sexual violence related by the three women. Rather, the women matter-of-factly refer to home in a way that is immediate and jarring. In some instances, this is conjoined with their expressions of longing for the domestic.

\section{Keisha: Incest, Dangerous Fathers, and "Trustworthy" Mothers}

One of the last Sundays in October was a busy day in the emergency room. Three cases had arrived for forensic examination at the same time. The second to be examined was Keisha, a teenaged woman who had been raped by her father in the early hours of the morning. From the hallway outside the family waiting room, I could hear an animated chorus of dissenting voices. Expecting a heated discussion, I knocked on the door and entered the room to find nine female family members of varying ages. Though the conversation reduced in volume, it continued steadily. I quickly identified Keisha, 
however, as she was the only silent person in the entire room. A woman sitting across from her quickly sprang up and introduced herself as "the mother," then ordered Keisha into the hallway to speak with me privately. This "private" exchange included the mother, however, and though I addressed myself to Keisha directly, including offering to leave if she found my presence overwhelming, it was her mother who spoke for her. When it became clear that she would not be allowed in the forensic examination with her daughter, Keisha's mother became very concerned that the nurse would offer her daughter a morning-after pill without consulting her. Forensic protocol barred a family member from accompanying Keisha into the examination. ${ }^{15}$

Keisha first spoke to me to indicate that she wanted me to accompany her during the forensic examination. Taking a cue from my training as a patient advocate, I assured her mother that Keisha would not be coerced into taking any medication, and that if Keisha were to accept the morning-after pill, it would most likely not have any permanent disabling effects on her reproductive system. "I heard that stuff can keep you from having babies ever," she frowned. Though she did not insist on being present at the examination, Keisha's mother was adamant that the forensic nurse provide her with further information about the morning-after pill before administering it, a message I passed on to the nurse before the examination started. Kelly was the nurse examiner on-call that morning. As we walked to the examination room and away from her mother, Keisha broke her silence for the second time and initiated a conversation about not wanting to be pregnant or sick.

Part of the pre-examination interview protocol requires the nurse examiner to ask the victim if the alleged assailant is someone known to her. If the victim answers in the affirmative, the nurse will ask for a name. When Kelly finally got around to asking Keisha who the perpetrator was and if she knew him, Keisha wrinkled her nose at the question and answered directly, "Did I know him? Yea, he was my father." In response, Kelly gasped and immediately recomposed her face and said, "Well, he wasn't acting like a father now, was he." In my role of patient advocate, I asked Keisha whether she felt safe returning home. She was surprised when I asked this question-"I hadn't thought about that, but actually," she seemed to be testing out

Home Cultures, Vol. 5, No. 3 (November 2008): pg. 301-325. DOI. This article is (C) Bloomsbury Publishing and permission has been granted for this version to appear in e-Publications@Marquette. Bloomsbury Publishing does not grant permission for this article to be further copied/distributed or hosted elsewhere without the express permission from Bloomsbury Publishing. 
a few possibilities, "he's been arrested for violating his parole with what he did to me, so I guess, yea, I'm alright cause he's gone straight to jail. He just got out yesterday after four years for something he did to me before."

In the pre-examination interview, Kelly asked where the sexual assault had taken place. When Keisha indicated she had been raped in her home, Kelly followed up by asking Keisha to be more specific. The exchange followed along these lines.

KELLY: What room were you in?

KEISHA: My father took me down to the basement.

KELLY: Did anyone else notice you were gone?

KEISHA: There were a lot of people. It was a party.

KELLY: Did you shout? Did anyone hear you?

KEISHA: It was loud. No one heard. He left after he was done and went back to the party.

The party was in celebration of Keisha's father's return from prison and had continued from the previous evening into the morning. As best as Kelly could approximate, the attack had taken place at approximately 7:00 am. The forensic examination began about four hours later at 11:00 am. It was the second exam of the day for the program, but the first during Kelly's shift. She felt that the chances of finding evidence during Keisha's examination were very promising since the attack was in the recent past. Underneath the blue light of the Wood's Lamp, Kelly's prediction proved true. ${ }^{16}$ Keisha had been standing during the attack. With the assistance of ultraviolet light, we could see that both her legs were covered with rivulets of some substance that, to the nurse examiner's experienced eye, fluoresced in a manner characteristic of semen. The image of Keisha's fluorescing legs was both dramatic and impacting. Kelly spoke longingly of some way to show the jury what she was seeing. She experimented with a $35 \mathrm{~mm}$ camera, the MedScopeTM videographic camera, and different combinations of lighting for several minutes to see if she could create a photographic image of the legs. She sketched the glowing areas onto 
a body map and then collected dry and wet swabs from five different regions of Keisha's legs. Afterwards, she expressed frustration with the technological limitations on her efforts to collect evidence. A clear image of Keisha's fluorescing legs could only be created using digital photography equipment currently unavailable at City Hospital.

Soon after the exam ended, Keisha's mother was allowed into the examination room. Kelly recommended to her that both of them seek therapy, handing them several brochures and phone numbers for counseling services. She also explained that Keisha had elected to take the morning-after pill, norgestrel, and that the first dose had been administered. A second dose should be administered in exactly twelve hours. ${ }^{17}$ Keisha's mother mentioned her earlier misgivings about the effects of emergency contraception on her daughter's fertility. Kelly assured her that the pill would not have permanently damaging effects. She reasoned, "I mean, you don't want her to get pregnant now, right?" She then handed an envelope containing the pills to Keisha's mother-the time for the second dosage was written on the envelope in thick, black magic marker. Kelly warned that Keisha may experience nausea and that she should eat something before the second dose: "If she throws up, you have to call us because then the pills won't work."

Keisha's assurance that her father had been arrested and immediately jailed on the grounds of parole violation did not allay my uneasiness with Kelly's apparent confidence in entrusting all of Keisha's care to her mother. Neither Kelly nor the police had made inquiries as to whether Keisha would be returned to a safe environment. As her guardian, Keisha's mother might be an especially suspect caretaker since she seemed unable to shield Keisha from her father's past and recent abuses. Nor was Kelly unaware of the aura of suspicion that Keisha's mother carried. In her conversation with Keisha's mother about the morning after pill, Kelly had been frustrated by concerns that the pill would render Keisha sterile. Afterwards, she shared with me how this had upset her, "Did she [the mother] actually want her [the daughter] to bear her father's child?" Yet the nurse had given the second dose of contraception, discharge instructions, and referral information to the mother alone. ${ }^{18}$ The intervention expressly excluded a systematic evaluation of whether the home the victim returned to was safe as it would have should Keisha have opted not to

Home Cultures, Vol. 5, No. 3 (November 2008): pg. 301-325. DOI. This article is (C) Bloomsbury Publishing and permission has been granted for this version to appear in e-Publications@Marquette. Bloomsbury Publishing does not grant permission for this article to be further copied/distributed or hosted elsewhere without the express permission from Bloomsbury Publishing. 
undergo forensic examination and been tracked through the emergency room as a gynecological patient. Her examination would have included screening for infections, and medication. Finally, the nursing care plan would have called for an assessment of the patient's home environment. This step is routinely omitted, or circumvented, in the forensic examination process. ${ }^{19}$

Keisha's family, however, had many concerns about her wellness beyond the emergency room. When I walked back to the waiting room with Keisha and her mother, another one of Keisha's family members jumped up, hugged Keisha, and asked to speak with me in private. "I'm Alecia, Keisha's aunt," she told me in the hallway while shaking my hand. Alecia identified herself as the one who had called the police since Keisha came to her first. "I want to know what we have to do now. I don't think it is a good idea for only-one person to have the instructions." The one person to whom Alecia referred was obviously Keisha's mother, and by indicating that Keisha had placed her confidence in Alecia rather than her own mother, Alecia signaled that Keisha did not necessarily trust her mother. It was only then that I realized the heated conversation I had overheard earlier that morning was around Keisha's mother's reasons for letting the father return to their home. Keisha's grandmothers, aunts, and cousins were upset that he had been allowed into the home given his known history of abuse against his daughter. I, like the rest of her family, found it unsettling that Keisha's mother had allowed her child's father back into the home after he had already abused their daughter. Though our suspicions about the mother dangerously toed the line of assigning blame, I agreed with Alecia's concerns that Keisha's care not be entrusted solely to her mother. Alecia understood all of the mother's apparent concern for Keisha to be outward manifestations of her guilt.

\section{Laura: "Cleaning House" After Domestic Violence and Sexual Assault}

Laura was the first victim to undergo forensic examination on that same Sunday in October. Kelly had not yet arrived at the hospital, so the nurse examiner coming off of the all-night shift took her case. Laura was relieved to have someone with her as she was currently waiting in the emergency room alone, although she did tell me that some friends of hers, doctors who worked at the hospital, had driven

Home Cultures, Vol. 5, No. 3 (November 2008): pg. 301-325. DOI. This article is (C) Bloomsbury Publishing and permission has been granted for this version to appear in e-Publications@Marquette. Bloomsbury Publishing does not grant permission for this article to be further copied/distributed or hosted elsewhere without the express permission from Bloomsbury Publishing. 
her there and were waiting to take her home. In the three hours we spent together, Laura shared with me the enormous bad luck that had followed her for the past ten years of her life. "I thought I was getting back on my feet and then this happened!" "This" was a sexual assault that had taken place two days earlier in Laura's home. After a difficult divorce that left her with very little in the way of financial assets, Laura had started over, moving to Baltimore and leaving behind an abusive husband. A physical therapist, she worked at two hospitals over an eight-year period before losing her job because of budget cuts. Now working retail to make ends meet, Laura had been raped in her home by a co-worker who had begged for a place to stay on Friday evening. Her role as a host extending hospitality to a co-worker she believed to be stranded was subverted: Laura's co-worker attacked his "host." "I can't believe it, I just can't believe it-it's one more thing, just one more thing." This she repeated many times at different points during her hospital stay. "I hope it is the last thing, because I can't take any more," she told me.

She described to me how after the attack, she had locked herself in her room, emerging the next morning and leaving the house with her dog, who had been injured during the attack. She was unsure if the attacker was still asleep in the guest bedroom. During the course of the day, she ran errands and kept her appointments. "It was very important I didn't miss any of my appointments-I am not sure why I thought that but I stuck to it." This insistence on persisting with her routine may be understood as Laura's disavowal of rupture in favor of continuity. Returning to her house that evening, she was relieved to find that her co-worker had left. She carefully collected bags full of "evidence," including all of the household implements he had touched, drank from or eaten out of, "I didn't know what to do with it, who to give it to or who to call, but I knew I had to keep it." This was evidence both of his presence in her home, and of his status as invited guest. Furthermore, Laura was attacked in her guest bedroom. Afterwards, she was surprised to see the sheets had been taken off of the bed and were nowhere to be found in the rest of the house. "When I saw that he had taken the sheets, I realized that even he knew he had done something wrong," she told me, "and so then I called a friend who told me 'Laura, you have to call the police.' My friend was a nurse and knew which hospital I would have to go to for the exam, so I called friends who worked at that hospital and they brought me here

Home Cultures, Vol. 5, No. 3 (November 2008): pg. 301-325. DOI. This article is (C) Bloomsbury Publishing and permission has been granted for this version to appear in e-Publications@Marquette. Bloomsbury Publishing does not grant permission for this article to be further copied/distributed or hosted elsewhere without the express permission from Bloomsbury Publishing. 
this morning." She described the thirty-six hours between the sexual assault and her arrival at the hospital as a complete blur.

When Laura went in for her forensic exam, she was asked to describe what happened by the forensic nurse examiner. The nurse was frustrated about the time that had passed between the rape attack and the forensic examination. As the nurse asked the required questions, the lulls during which she was writing down Laura's responses on the form were filled with Laura's ruminations of her situation, her awful luck and her hopes that this terrible event would mark the end of the unlucky period in her life and better times ahead. As soon as she had finished writing each question on the form, the nurse would interrupt Laura with the next question. Laura would respond and then continue reflecting on the difficulty of extracting herself from the violence of her marriage, and the subsequent hardship of living life as a single divorcée concealing her whereabouts from her ex-husband. In this way, Laura's third turn describing her attack was interspersed with her own understanding of the significance of this rape, its place in the life she had been living these many years, and its indications for the future. As the third in a series of tribulations, Laura felt certain that rape marked the end of her bad luck. The official narrative entered into the nurse's records would have no mention of these circumstances, and the recommendations the nurse provided, "Make sure you follow up with therapy; these things can be very hard to get through," seemed not to engage with the grain of hope planted in Laura's pining for the end of bad luck and the possibility of fates, or a creator, or a universe or cosmic force which would not be so cruel as to allow her to continue suffering. "I'm so glad I came in," she told me. "It has to get better from here on out."

\section{Leda: The Fleeing Domestic Violence Victim as "Repeat Customer"}

Leda was a "repeat customer." Maude, the forensic nurse examiner on shift, told me this under her breath when I reached the emergency room. During my time in the field, I had never met any of the repeat customers that nurses whispered and gossiped about. While patient advocates were often requested immediately upon a victim's arrival in the emergency room, in this case I had been called after the forensic examination as per the victim's request. Leda was perched on

Home Cultures, Vol. 5, No. 3 (November 2008): pg. 301-325. DOI. This article is (C) Bloomsbury Publishing and permission has been granted for this version to appear in e-Publications@Marquette. Bloomsbury Publishing does not grant permission for this article to be further copied/distributed or hosted elsewhere without the express permission from Bloomsbury Publishing. 
a hospital bed only a few yards behind Maude, but the general tumult of the emergency room covered Maude's emphatic whisper. Perhaps Leda saw Maude jerk a thumb over her shoulder to gesture in Leda's direction. In the parlance of sexual assault forensic nursing, a "repeat customer" is an individual who frequently reports to the emergency room alleging sexual assault.

In the emergency room, patients are also clients. "Customer" suggests the self-consciousness of the economics of healthcare, a field that has been addressed at length in the anthropological research on privatization of healthcare, managed care, and welfare reform (Lamphere 2005). Many interviews with forensic nurse examiners revealed that the myth of the false report of rape is often tied to the imaginary of destitute and/or uninsured women seeking healthcare. Specifically, women are thought to be using the system to access free emergency contraception following bad or unplanned sex. The presence of "customers" in the emergency room also draws on another type of financial exchange. I had been told, both by nurses and police officers, that repeat customers were mostly sex workers who would "cry rape" if they were refused payment.

In addition, women who regularly relied on hack drivers for transportation were included in the repeat customer category. This is the local term describing unofficial taxi services offered by private drivers. ${ }^{20}$ Determined not to ask Maude to identify the circumstances that led her to label Leda a repeat customer, I felt confused when I turned towards Leda and took in her appearance. I immediately dismissed the possibility she could be a sex worker, and then mentally chided myself as I had been surprised by appearances before. Wearing tweedy trousers, a button-down shirt, and stylish tortoiseshell spectacles, Leda's attire was that of a businesswoman. Though a few unruly strands hung in her face, her hair was exquisitely cut, colored, and styled. Her facial expression was blank; her red-rimmed eyes drifted from object to object resting nowhere in particular as she stood leaning on her hospital bed. One eye was clearly showing signs of a contusion-it would turn black and blue by the end of our conversation. I noticed a profusion of red welts peeking out of the top of her blouse and on the side of her neck.

What Leda ultimately told me about her "path" to the emergency room was very unexpected given Maude's labeling of her

Home Cultures, Vol. 5, No. 3 (November 2008): pg. 301-325. DOI. This article is (C) Bloomsbury Publishing and permission has been granted for this version to appear in e-Publications@Marquette. Bloomsbury Publishing does not grant permission for this article to be further copied/distributed or hosted elsewhere without the express permission from Bloomsbury Publishing. 
as a "repeat customer." Though I made an effort not to let Maude's introduction shape my expectations, I did not anticipate such a disparate gap between Leda's circumstances and the way she had been brought to my attention. What first became evident was that Leda had not been admitted to the emergency room for a forensic examination at all-she had been referred for a forensic examination after being treated and stabilized following a suicide attempt. When she related how her journey to the hospital had begun, she was quiet and understated. In response to my query as to how she had been transported to the hospital she said: "I tried to kill myself and they called an ambulance that brought me here." She rarely met my gaze when she spoke.

A month earlier, the police had brought Leda to the emergency room at City Hospital for a sexual assault forensic exam. Leda had recently fled from her husband after seven years of marriage. He was abusive and was becoming increasingly so. They had two children. She never spoke of their ages or whether they were boys or girls. She had called a local domestic violence hotline to find a shelter she could go to with her children. There was only one that had space for all three of them. It was, unfortunately, located in an inconvenient suburb to Baltimore, but Leda took the chance that she had been offered and took up residence in the shelter. She had a good job in the city, and every morning and evening, she would hack to and from work. There were no buses, taxicabs were much too expensive, and the shelter had not offered any transportation alternatives.

Three days after she began flagging down hacks to get herself to and from work, a driver pulled a gun on Leda and sexually assaulted her on the way home from work. Expelling her from the car in a remote area, he left her alive, scared, and humiliated. Leda had then flagged down a passerby who had directed her to the nearest pay telephone where she had called the police. They had brought her directly to the hospital where she had been treated, examined, and an investigation had been opened regarding the rape case. Social workers had watched Leda's children during this (first) forensic examination.

Back at the shelter after her emergency room visit, the staff and social workers still provided no alternative suggestions for budgetconscious transportation to and from work. Leda resolved to move on with her life, pick her rides more carefully, and continue to hack to and 
from work. After all, her job was one of a few positive factors of her circumstances-it was what had allowed her to leave her husband, and if she were patient, she would soon be able to provide her own home for her family. Putting her safety first meant picking drivers who were women, had women passengers in their cars, or appeared older and more "respectable." It also meant not compromising her means to a livelihood and maintaining her reputation as a reliable and responsible employee.

Almost four weeks following the first attack by a hack driver, Leda was once again hacking back out to the shelter after work. An older gentleman pulled over in response to her signal and offered her a ride. "He seemed nice, didn't even want any money," she frowned. Halfway home, she realized that he had veered off course. She politely inquired about the detour, and he began to shout and curse at her. Pulling into an alley, he locked the car doors and demanded sex. Leda thought she might be able to talk her way out of danger, though she felt fearful. If she could draw out the conversation, surely someone would walk by and see she was in distress? When he refused to respond to her pleas, she desperately demanded whether he had a gun or knife. She momentarily breathed a sigh of relief when he indicated he had no weapons in the car. Her relief was cut short when he began viciously beating her with his fists. He repeatedly bludgeoned her face, neck, and chest. "He didn't need a gun," she reflected, "he didn't need a gun." Terrified and in pain, Leda had cooperated with his demands in order to stop the beating. "I just begged him not to kill me."

"He actually dropped me off near the shelter," she told me. Leda had all her rides drop her off a few blocks away from her destination. "The place is a secret, so I couldn't tell anyone the address." She walked the remaining distance to the shelter, entered, walked straight to the bathroom, and found herself looking under the sink. Among the cleaning products was a bottle of Pine-Sol. She had swallowed most of the contents of the bottle. She did not disclose how and who discovered her attempt at self-poisoning and subsequently called the ambulance. "What do you want to do now?" I asked, concerned. "I need to see my kids. Get back to the shelter. There is a curfew and I want to get back there before..." 


\section{Forensic Examination: The Presence of Home on the Body}

How can the cases described here lend insight into the great distance between the homes that are spoken of and the homes to which forensic nurse examiners prescribe the victim's return in discharge instructions? What are the mechanisms through which this "distance" is achieved? It is not my purpose to vilify Maude, Kelly, and the third nurse examiner, or to suggest that the problem is the particular callousness and insensitivity of these nurse examiners. All three women are exemplary in that they have impeccable reputations as professional and competent nurse examiners; other nurse examiners, patient advocates, and victims have responded to their kindness and competence. Parnis and Du Mont have pointed towards nurse examiners' lack of uniform adherence to forensic examination protocol as infringing on the welfare of sexual assault victims (Du Mont and Parnis 2001: 70; Parnis and Du Mont 2002: 849, 851-2). Numerous training manuals, on the other hand, suggest that forensic nurse examiners develop their own style of examination practice, which may include modifying the order of procedures (Crowley 1999: 64).

I argue, however, that neither the personal attributes, nor biographies, nor exam styles of forensic nurse examiners are the sole factors driving the consistent disarticulation of the harmful and healing aspects of the domestic within proffered remedies of sexual assault intervention. Equating the body as scene of the crime is more than an adage and a directive-it is a process constituted within the scopic regime of forensic science. Daily and weekly repetition and routinization of the procedures of forensic examination insures that nurse examiners internalize the techniques of forensic intervention, thus deploying the scopic regime through which the domestic encompasses both the harmful and the healing. Thus, I am not asserting that the forensic examination is irrational, in the sense that evidence is simply ignored and contradictory conclusions are drawn (Dawes 2001: 93). Nor am I suggesting that there is deliberate and intentional manipulation of a set of facts in order to maintain a blind spot where the domestic is concerned. This is not a case of what Faigman (1999) terms "legal alchemy" in which the law misinterprets or misappropriates science.

Home Cultures, Vol. 5, No. 3 (November 2008): pg. 301-325. DOI. This article is (C) Bloomsbury Publishing and permission has been granted for this version to appear in e-Publications@Marquette. Bloomsbury Publishing does not grant permission for this article to be further copied/distributed or hosted elsewhere without the express permission from Bloomsbury Publishing. 
The Maryland State Police Victim Sexual Assault Evidence Collection Kit (henceforth "Evidence Kit") produces the routine through which nurse examiners develop their forensic sensibility. Per the instruction sheet included in the Evidence Kit, there are seventeen possible steps to every forensic examination. "Step 1 " is listed as the "Medical Examination and Report of Alleged Sexual Assault Form." Every forensic examination begins with an interview that is structured by the information that must be recorded on the report form. The interview questions are a standard feature of the official Evidence Kit. Posing each question serves two purposes. The first is to make another official record of the victim's narrative to serve as a point of comparison with the police statement made earlier. Thus, the victim's responses are all documented in the Evidence Kit. Additionally, these answers serve as a guide for the examination itself. Like many of their colleagues in the medical world, forensic nurse examiners in Baltimore, Maryland, learn to "see" probabilistically, particularly when it regards the body of the sexually violated subject. Forensic techniques, though aiding in the visualization and collection of physical evidence, must be targeted for maximum effectiveness. Thus, nurse examiners allow their vision to be guided to the parts of the victim's body where injury has the greatest likelihood of occurring (Girardin et al. 1997:41). The victim's narrative, elicited in the interview, alerts the nurse examiner to areas of the body on which to focus. For example, a report of strangulation calls for a search for evidence of burst blood vessels in the eyes, throat, nasal, and vaginal tissue and bruising or contusing where the air vessels were restricted. ${ }^{21}$ Similarly, a report of being attacked while the victim is on her back would draw the eye to one locus of the genitals during the pelvic examination while a report of being attacked while prone would draw the eye elsewhere (Crowley 1999: 88).

In both Keisha and Laura's case, the nurse examiner is engaged in pre-examination questioning. Many items on the examination form require very specific questioning. The opening questions typically include asking for the victim's name, address, phone number, date of birth, sex, and race. It is then that the forensic examiner moves to the more specific and "intimate" questions. Further items ask for the last date on which the victim engaged in consensual intercourse, and related questions in order to ascertain whether there is a possibility of

Home Cultures, Vol. 5, No. 3 (November 2008): pg. 301-325. DOI. This article is (C) Bloomsbury Publishing and permission has been granted for this version to appear in e-Publications@Marquette. Bloomsbury Publishing does not grant permission for this article to be further copied/distributed or hosted elsewhere without the express permission from Bloomsbury Publishing. 
finding semen or DNA from more than one individual during the examination.

This also helps to establish the extent to which genital injuries might be caused by sexual activity taking place before or after the sexual assault. The next question asks whether a condom was used in the assault. The examiner has the option of selecting among the following three responses: 1) Yes, 2) No, and 3) Unknown. The forensic examination is interested in the domestic through narrowly defined parameters. The victim's home address provides a literal home address through which to locate and contact the victim. No single field provides a space for the location of the alleged assault, though the date and time of the assault, the date and time of police notification, and the date and time of the examination are noted at the outset. Another field requires the recording of the location of the examination. The location of the assault is pertinent to evidence collection in that findings on the body are often directly related to the site of assault, and indicative of features or traces that crime scene investigators might focus on or search for when inspecting the crime scene.

While most fields on the form require a single-word response, or selecting from among a limited range of choices, not all of the items on the report form call for clearly defined short-answer responses. When Kelly asks Keisha, "Did you know him?" she is probing for information that will allow her to complete a less-defined item on the report form. This question does not correspond to a particular blank space, but rather is asked under the heading of "Description of assault (as related to examiner)." An additional instruction directs the nurse examiner to use the enclosed Maryland State Police Note form, providing an entire $8 \frac{1}{2} \times 11$ inch sheet for the recording of a narrative. As part of her notes, the examiner commonly includes the location of the sexual assault on this form. In cases where the assault has transpired in the victim's home, the domestic appears within the records as both location of assault and home address. Within the description of the assault, the nurse would also record the identity of the assailant, potentially the name of a spouse, relative, or intimate, either current or former. This information appears nowhere else in the Evidence Kit. A further instruction on constructing the narrative advises nurse examiners to "Give description of pertinent details of the assault: oral, rectal, vaginal penetration; digital penetration or use of a 
foreign object; oral contact by assailant; oral contact by victim; ejaculation and location of such, if known by victim."

While this instruction emphasizes the "pertinent details of the assault" by focusing on sexual acts and violent force, the domestic potentially appears once again within such details vis-à-vis the referenced "foreign object." Here, foreign objects are of forensic interest only if they have been used to penetrate the victim's body, putting a familiar or household object to menacing use. The significance of household objects in narratives of violence is often discussed in cases of torture; our attention is drawn to objects when they are implements of torture. In describing the structure of torture, Scarry links the act of torture to the making and unmaking of the victim's world. She does not locate suffering solely in the body, but connects it to the familiar environs in which the torture victim lives, is tortured, and "returns." In Scarry's description of torture, familiar people, objects or locations are rendered unfamiliar through their participation in the act of torture (i.e. the chair or cup as weapons or restraints) (1985: 20,38). The cases I observed differ in that they suggest that the home and the objects and rooms in which sexual violence often occurs remain familiar. Victims did not allude to the foreignness of objects used against them in a rape attack. Rooms and objects are often put to the same uses they are put to in daily life, and descriptions of being sexually assaulted within the home were full of familiar objects and locations. Tissues from boxes on bedside tables were used to wipe away evidence. When Laura collects and "bags" all of the implements touched by her co-worker, they are the glasses and bottles from which he had drunk. The familiar world of the domestic is never unmade into a space of alien terror by transforming objects into other than what they are. The object contains within it the potential to terrorize or to comfort through its appropriate use. When a bed in the home becomes the site of rape, is this transforming the bed into something other than a bed, or transfiguring it from comforting or sensual in one instant to terrifying and menacing in the next?

Home and domestic life materialize in the rest of the examination as physical trace evidence. The location of sexual assault, either the home or any other place, may be substantiated in any of the following examination entries: 1) Foreign Substance Recovered, 2) Debris Collected, 3) Fingernail Scrapings, or 4) Miscellaneous 
Collection. In these categories, evidence, such as carpet fibers or paint flakes, found on the victim locate the body in a particular space. Home can literally be scraped from underneath the fingernails, or tweezed off the clothing. Injuries constitute another category of examination through which the home can be present in the forensic documentation, for example through a scrape or cut caused by a specific abrasive surface. A common example would be carpet burns.

While the forms in the Maryland State Evidence Kit are fairly typical of forensic examination documentation, documents vary from state to state. Subtle variations in documentary fields can figure the home and the domestic within the forensic examination in very different ways. California, for example, explicitly includes the possibility of parental victimization of children at the outset. California Civil Code $\S 34.9$ is referenced in the form's header. These rules regard the examiner's obligation to notify parents or guardians in the case of an under-age victim. Parents must be contacted unless the examiner "reasonably believes the parent or guardian committed the sexual assault on the minor." In addition, the location of the assault is given its own field and labeled as: "Location and physical surroundings of assault (bed, field, car, rug, floor, etc.)." In this version, the potential sites of a sexual assault include both familiar and unfamiliar spaces. These locations are intermixed without regard to whether they feature within domestic or non-domestic spaces. Compare this with the Maryland forms, which, as stated earlier, lack a designated field for recording the location of the sexual assault. The location "home" is buried within the narrative note, or materialized as trace evidence.

Returning to Leda's case, she is the only victim among the three who has no home to which she can return. On the circuit of domestic violence advocacy, Leda's narrative may exemplify successful escape. She has fled the site of perpetual victimization at the hands of her exhusband. When I encountered Leda, it was only following her forensic examination. Maude had already completed her interview and all steps of the examination. When Maude introduced me to Leda as a "repeat customer," she saw Leda as someone who frequently elected to take risks. Leda's return to the emergency room within a month from her first visit contributed to this impression.

Maude does not have access to Leda's earlier case file. However, Leda's name and earlier case number are recorded in the Forensic

Home Cultures, Vol. 5, No. 3 (November 2008): pg. 301-325. DOI. This article is (C Bloomsbury Publishing and permission has been granted for this version to appear in e-Publications@Marquette. Bloomsbury Publishing does not grant permission for this article to be further copied/distributed or hosted elsewhere without the express permission from Bloomsbury Publishing. 
Program register and her last admission to the hospital is recorded within the medical chart. ${ }^{22}$ The only potential trace evidence on Leda's body would correspond to the cars in which she had been assaultedthe physical traces of Leda's chaotic domestic world were nonexistent. The significance of her travel to and from home gives way to the other patterns of her victimization; namely, that she commonly hacks and that hacking is a risky business.

\section{Living (and Writing) the Domestic: Concluding Thoughts}

How does disarticulating two aspects of a domestic come to bear on the relationships of Keisha, Laura, and Leda to home? Or if one were to consider, specifically, forensic documentary practices, "how does the broader speech/writing attitude structure the relationship of this specific type of legal text to the human relationship of the world" (Messick 1989: 26) ${ }^{23}$ One direct result of the inscription of two domestics within a set of paperwork is to preserve these domestics in enduring form as legal text (Messick 1989: 27). However, although a legal text, the documentation carries in it therapeutic import. ${ }^{24} \mathrm{By}$ separating the risks of violence inherent within domestic intimacies from the healing aptitudes of the domestic, forensic nurses can issue prescriptions for victim's to return home. Accordingly, Keisha and Laura are sent home. Moreover, being sent home reflects their desire to return home. It is I, as patient advocate, who questions the safety of Keisha's home. When Keisha considers her safety in response to my query, she assesses her home as safe and dismisses its dangers. Her father, the perpetrator in this instance, has been taken back into custody. Her kinfolk, including Aunt Alecia, already suspicious of Keisha's parents, will be able to keep Keisha in their sights. Leda, who does not have a home to return to, as she is in the process of escaping from it, is dubbed a "repeat customer."

Leda and Laura could be said to have a common history of flight from the domestic. But what distinguishes one from the other is the chronology of victimization and the enterprise of homemaking. Laura's days of domestic violence are ten years behind her, and she has attained a home. Leda, who is haunted by the violence of the domestic life she shared with her husband in the recent past, is not yet able to find a way home. The scenic nature of the crime of sexual assault, as

Home Cultures, Vol. 5, No. 3 (November 2008): pg. 301-325. DOI. This article is (C) Bloomsbury Publishing and permission has been granted for this version to appear in e-Publications@Marquette. Bloomsbury Publishing does not grant permission for this article to be further copied/distributed or hosted elsewhere without the express permission from Bloomsbury Publishing. 
described by forensic nurses and in relationship to the victimized body, prevents Leda's body from being linked to a home, least of all her own home. Leda's body, the scene of two crimes, bears no traces of home-it is simply a parchment of her displacements (Cavell 1995: 87). Her displacements appear to continue into the future. As an attempted suicide and known hacker, the domestic violence shelter set in motion a process to evaluate whether Leda and her children would be offered continued residency within the shelter. Within the scopic regime of forensic intervention, the state, in the person of the forensic nurse, sees no home of return for Leda. Even as one victim is returned to a domestic arrangement in which she will have limited recourse for healing or restoration, it is the disarticulation of the healing and hurting qualities of the domestic in the forensic scopic regime that allows the state to avoid paralysis or inaction while acknowledging its own inability to affect a complete repair.

\section{Acknowledgments}

This project was generously supported by the Social Science Research Council's Sexuality Research Fellowship Program, in cooperation with the Ford Foundation, as well as a Dissertation Research Improvement Grant from the Law and Social Science Program of the National Science Foundation. I must also thank Valeria Procupez, Aaron Goodfellow, Veena Das, and Deborah Poole for their comments and questions, as well as the organizers of the Bodily Proofs conference at the Humanities Center of Harvard University where this article was first presented as a paper.

\section{Notes}

1. The title of my article recalls Dorothy's desire to return home to Kansas after being transported to the fantastic and menacing Land of $\mathrm{Oz}$ in the classic film, The Wizard of Oz based on the 1900 story The Wonderful World of Oz by Frank Baum. "There is no place like home," she chants, her desire transporting her to the home for which she has suffered a terrific and trying journey through Oz. For the viewer, the domestic idyll for which Dorothy longs is also the farmhouse yanked off the face of the earth by the tornado in the opening sequence. Also unremarked on is Dorothy's status as an orphan.

Why is Dorothy in Auntie Em and Uncle Henry's care to begin with? These potentially sinister answers do not dull the edge of Dorothy's desire for home. 
NOT THE PUBLISHED VERSION; this is the author's final, peer-reviewed manuscript. The published version may be accessed by following the link in the citation at the bottom of the page.

2. The categories of "stranger" or "simple" vs. "acquaintance" rape are further subdivided in the profiling of perpetrators (see, for example, Holmes and Holmes 2002: 139-56).

3. Location figures only as a generic site: a space where one returns to find material evidence, or to locate potential witnesses. It is also, as I will discuss later, an indicator of what material traces are likely to be found on the body of the sexual assault victim if her account is truthful.

4. In this article, I sometimes use the terms domestic and home interchangeably. In doing so, I am not suggesting that they are always the same thing. It is simply that at times they are mutually inclusive.

5. The concept of a scopic regime, as discussed in Martin Jay's (1998[1988]) "Scopic Regimes of Modernity," and elaborated by many others, including W. J. T. Mitchell (1995) and Christian Metz (1985), typically refers to culturally and/or historically specific ways of seeing. It is neither solely characterized by social constructionism nor technological determinism. Rather, the social and technological are both constitutive of a particular scopic regime. The concept also suggests that contemporary modes of perception can vary from one another. Thus, in the case under discussion, the scopic regime of the forensic and the anthropological may overlap in some respects.

Ultimately, however, each sexual assault victim comes to be "seen" quite differently as an ethnographic vs. examination subjects.

6. Informed consent practices were observed. I participated in the full training of a rape and domestic violence victim's advocate. All victims were told that I would be writing notes on the cases after leaving the hospital. I also offered not to include any victims who did not wish to participate, and serve only as patient advocate. No victim ever asked me to exclude his or her case from my project. No recording or writing of any kind was done in the hospital or during the rape interventions, except for paperwork pertaining to my role as a patient advocate, which I did not keep but turned over to the local rape crisis center. I also did not ask any questions of the victims outside of my role as patient advocate, nor did I seek contact with victims beyond the hospital visit. Thus, all information that I was told about these cases was volunteered in the context of a crisis intervention. The rape crisis intervention is so highly structured that I did not feel comfortable imposing another layer of organization or interrogation on the victims.

7. The cases I have selected to make the argument in this article happen to involve female sexual assault victims. I did, however, observe five

Home Cultures, Vol. 5, No. 3 (November 2008): pg. 301-325. DOI. This article is (C) Bloomsbury Publishing and permission has been granted for this version to appear in e-Publications@Marquette. Bloomsbury Publishing does not grant permission for this article to be further copied/distributed or hosted elsewhere without the express permission from Bloomsbury Publishing. 
NOT THE PUBLISHED VERSION; this is the author's final, peer-reviewed manuscript. The published version may be accessed by following the link in the citation at the bottom of the page.

male victims during my research period, and the conclusions that I make apply to their cases as well.

8. Applying a calculative statistical assessment to the sense of "home" is not a practice that should be applied uncritically (Poovey 1998, T. Porter 1995), nor can it be assumed that statistics or data about the home are easily collected and interpreted (Nations and Amaral 1991).

9. For this insight I thank Valeria Procupez who first brought this to my attention in relation to the case of Argentina, and then reminded me of the many other circumstances in which one was vulnerable to political violence in the home, in particular with regard to abduction and "disappearance" as home was the place one was most likely to be found.

10. The aggressive insistence on domestic bliss in the USA is most often associated with post-World War II modernist architectural movements. The postwar home was forcefully "happy." Home was not simply a "backdrop" against which life was lived, but a way of living. The space of the home associated with everyday life was deliberately folded into a particular domestic (Colomina 2007: 5-20).

11. The significance and import of incest and marital rape are not fixed but informed by the particular historical and social framing of each instance.

12. Smock is referring to Blanchot's comments on the primal scene (Blanchot 1986: 72). For further structural features of the scenic in relation to the domestic, see Weber (1999).

13. The "body as the scene of the crime" orientation is not limited to Baltimore, MD. I found numerous references to it in training curriculums, though the phrase is conspicuously absent from many mainstream forensic nursing textbooks. It also appears in police training manuals and law enforcement journals. See, for example, Larry Jetmore's 2006 column in which he writes, "in a rape there are two crime scenes: the location where the rape took place and the rape victim's physical person, including the clothing worn by the victim and the perpetrator." This is the only direct reference I have found to the perpetrator's body being included in the locus of "crime scene." As for Jetmore's inclusion of the perpetrator's clothing as an extension of the "rape victim's physical person," this association seems unintentional. However, it is suggestive in that the perpetrator is erased except as a force acting on and constituting the victim's body.

Home Cultures, Vol. 5, No. 3 (November 2008): pg. 301-325. DOI. This article is (C) Bloomsbury Publishing and permission has been granted for this version to appear in e-Publications@Marquette. Bloomsbury Publishing does not grant permission for this article to be further copied/distributed or hosted elsewhere without the express permission from Bloomsbury Publishing. 
NOT THE PUBLISHED VERSION; this is the author's final, peer-reviewed manuscript. The published version may be accessed by following the link in the citation at the bottom of the page.

14. In the introduction to Body Parts: Critical Explorations in Corporeality, Forth and Crozier (2005) open with a description of Desbonnet's dream of his organs withdrawing to the corner of the bed. Desbonnet describes the dream as atypical, and an unconscious rewriting of a conversation he overheard the previous evening among some disgruntled servants who undertook small arts of sabotage to revenge themselves on their employer. Desbonnet described this dream at great length in La Santé par les sports; including an illustration that depicts his brain, heart, lungs, stomach, and intestines evacuating his body and conversing among themselves.

15. This may be an indication that the protocol is suspicious of the family as well. Forensic nurses, however, commonly explained the ban as freeing the victim to speak without embarrassment or shame.

16. The Wood's Lamp is an ultraviolet light source. In a room that has been darkened completely, fluids and substances of organic origin will fluoresce in a particular way. Thus, a Wood's Lamp can be used to locate bite marks, saliva, blood, and semen that cannot be seen with the naked eye.

17. This is often circulated under the brand name "Ovral." Other pharmaceutical options, such as Plan B, exist, but the City Hospital program currently uses Ovral.

18. In cases where a victim is thirteen-years-old or above, she is considered an emancipated minor for the purposes of legal participation and medical care. Thus, there was no legal requirement that Keisha's care fall to her mother.

19. Sexual assault victims can be placed in emergency shelters if the need arises. Baltimore-based patient advocates provide the placement service for both domestic violence and sexual assault victims when appropriate.

20. By many accounts, public transport is notoriously unreliable in Baltimore City. Many passengers have cell phone numbers for "regular" hack drivers who they call on routinely. It is cheaper than a taxi service, and though illegal, often the only means travelers have for getting across town quickly. If one's regular hack driver is unavailable, an informal hack may be flagged down through a series of hand gestures that indicate the direction in which one is seeking transport.

21. The burst vessels are known as petechiae (Crowley 1999: 41, 81).

22. In compliance with health privacy laws, I did not have access to medical charts. However, I was shown a sample chart. Prior admissions to the

Home Cultures, Vol. 5, No. 3 (November 2008): pg. 301-325. DOI. This article is (C) Bloomsbury Publishing and permission has been granted for this version to appear in e-Publications@Marquette. Bloomsbury Publishing does not grant permission for this article to be further copied/distributed or hosted elsewhere without the express permission from Bloomsbury Publishing. 
NOT THE PUBLISHED VERSION; this is the author's final, peer-reviewed manuscript. The published version may be accessed by following the link in the citation at the bottom of the page.

hospital remain in the chart. Visits for sexual assault forensic examination carry the shorthand "ASA": alleged sexual assault.

23. See also Navaro-Yashin (2007) for how documents effect, retain, and carry affect. This question need not be posed simply in relation to bureaucratic forms, but all representative modes that are legally recognized as annotation. For example, Povinelli considers the place of family trees in Australian aboriginal land claims, and how "their social relevance was in fact democratized and dispersed into the life-world of ordinary people" (Povinelli 2002: 218).

24. In the intimate-domestic domain, Berlant states, "jurisprudence has also taken on a therapeutic function...notably as it radically recasts interpretations of responsibility in cases of marital and child abuse" (2000: 1). In fact, Nolan (1998) argues that the increase of therapeutic intervention in adjudicating criminality is a recent reorientation of the juridical function of the US state.

\section{References}

Berlant, L. (ed.). 2000. Intimacy: A Special Issue, In Intimacy, pp. 1-8. Chicago, IL: University of Chicago Press.

Blanchot, M. 1986. The Writing of the Disaster. Trans. Ann Smock. Lincoln, $\mathrm{NE}$, and London: University of Nebraska Press.

Brochman, S. 1991. "Silent Victims: Bringing Male Rape out of the Closet." The Advocate 582: 38-43.

Cavell, S. 1995. A Pitch of Philosophy: Autobiographical Exercises. Cambridge, MA, and London: Harvard University Press.

Colomina, B. 2007. Domesticity at War. Cambridge, MA: MIT Press.

Crowley, S. 1999. Sexual Assault: The Medical-Legal Examination. Stamford, CT: Appleton and Lange.

Das, V. 2006. Life and Words: Violence and the Descent into the Ordinary. Berkeley, CA: University of California Press.

Das, V., A. Kleinman, M. Lock, M. Ramphele and P. Reynolds (eds). 2001. Remaking a world: Violence, Social Suffering, and Recovery. Berkeley, CA: University of California Press.

Dawes, R. 2001. Everyday Irrationality. Boulder, CO: Westview Press.

Du Mont, J. and D. Parnis. 2001. "Constructing Bodily Evidence through Sexual Assault Kits." Griffith Law Review 10(1): 63-76.

Estrich, S. 1988. Real Rape: How the Legal System Victimizes Women Who Say No. Cambridge, MA, and London: Harvard University Press.

Faigman, D. 1999. Legal Alchemy: The Use and Misuse of Science in Law. New York: W. H. Freeman and Company.

Home Cultures, Vol. 5, No. 3 (November 2008): pg. 301-325. DOI. This article is (C) Bloomsbury Publishing and permission has been granted for this version to appear in e-Publications@Marquette. Bloomsbury Publishing does not grant permission for this article to be further copied/distributed or hosted elsewhere without the express permission from Bloomsbury Publishing. 
NOT THE PUBLISHED VERSION; this is the author's final, peer-reviewed manuscript. The published version may be accessed by following the link in the citation at the bottom of the page.

Fineman, M. A. and R. Mykitiuk (eds). 1994. The Public Nature of Private Violence: The Discovery of Domestic Abuse. New York and London: Routledge.

Forth, C. and I. Crozier (eds). 2005. Body Parts: Critical Explorations in Corporeality. New York and Oxford: Lexington Books.

Girardin, B., D. Faugno, P. Seneski, L. Slaughter and M. Whelan. 1997. The Color Atlas of Sexual Assault. St Louis, MO, and Philadelphia, PA: Mosby.

Holmes, R. M. and S. T. Holmes. 2002. Profiling Violent Crimes: An Investigative Tool, 3rd edition. London: Sage Publications.

Jay, M. 1998[1988]. "Scopic Regimes of Modernity." In Hal Foster (ed.) Vision and Visuality, pp. 3-28. New York: The New Press.

Jetmore, L. 2006. "Investigating rape crimes, part 2: evidence collection and analysis." http://www.policeone.com/writers/columnists/LarryJetmore/articles/1 39768/, accessed December 5, 2007.

Lamphere, L. 2005. "Providers and Staff Respond to Medicaid Managed Care: The Unintended Consequences of Reform in New Mexico." Medical Anthropology Quarterly 19(1): 3-25.

McKeon, M. 2005. The Secret History of Domesticity. Baltimore, MD: Johns Hopkins University Press.

Messick, B. 1989. "Just Writing: Paradox and Political Economy in Yemeni Legal Documents." Cultural Anthropology 4(1): 26-50.

Metz, C. 1985. "Photography and Fetish.". October 34: 81-90.

Mitchell, W. J. T. 1995. Picture Theory: Essays on Verbal and Visual Representation. Chicago, IL: University of Chicago Press.

Navaro-Yashin, Y. 2007. "Make-believe Papers, Legal Forms and the Counterfeit: Affective Interactions between Documents and People in Britain and Cyprus." Anthropological Theory 7(1): 79-98.

Nations, M. K. and M. L. Amaral. 1991. "Flesh, Blood, Souls and Households: Cultural Validity in Mortality Inquiry. Medical Anthropology Quarterly 5(3): 204-20.

Nielsen, B. 2005. "Home Invasion and Hollywood Cinema: David Fincher's Panic Room." In Dana Heller (ed.) The Selling of 9/11: How a National Tragedy Became a Commodity. pp. 233-253. New York: Palgrave Macmillan.

Nolan, J. 1998. The Therapeutic State: Justifying at Century's End. New York: New York University Press.

Office on Violence against Women. 2004. A National Protocol for Sexual Assault Forensic Examinations. Washington, DC. US Department of Justice, NCJ 206554.

Home Cultures, Vol. 5, No. 3 (November 2008): pg. 301-325. DOI. This article is (C) Bloomsbury Publishing and permission has been granted for this version to appear in e-Publications@Marquette. Bloomsbury Publishing does not grant permission for this article to be further copied/distributed or hosted elsewhere without the express permission from Bloomsbury Publishing. 
NOT THE PUBLISHED VERSION; this is the author's final, peer-reviewed manuscript. The published version may be

accessed by following the link in the citation at the bottom of the page.

Olshaker, J., M. C. Jackson and W. S. Smock (eds). 2006. Forensic Emergency Medicine: Mechanisms and Clinical Management, 2nd edition. Philadelphia, PA: Lippincott, Williams and Wilkins.

Parnis, D., and J. Du Mont. 2002. "Examining the Standardized Application of Rape Kits: An Exploratory Study of Post-sexual Assault Professional Practices." Health Care for Women International 23: 846-53.

Porter, R. and M. Teich. 1994. Sexual Knowledge, Sexual Science: The History of Attitudes to Sexuality. Cambridge and New York: Cambridge University Press.

Porter, T. 1995. Trust in Numbers: The Pursuit of Objectivity in Science and Public Life. Princeton, NJ: Princeton University Press.

Poovey, M. 1998. History of the Modern Fact: Problems of Knowledge in the Sciences of Wealth and Society. Chicago, IL: University of Chicago Press.

Povinelli, E. 2002. "Notes on Gridlock: Genealogy, Intimacy, Sexuality." Public Culture 14(1): 215-38.

Roth, M. and C. Salas. 2001. Disturbing Remains: Memory, History and Crisis in the 20th Century. Los Angeles, CA: Getty Research Institute.

Russell, D. E. H. 1990[1982]. Rape in Marriage: Expanded and Revised Edition. Bloomington, IN, and London: Indiana University.

Scarry, E. 1985. The Body in Pain: The Making and the Unmaking of the World. New York and Oxford: Oxford University Press.

Smock, A. 1986. "Translator's remarks." In Maurice Blanchot, The Writing of the Disaster. Lincoln, NE, and London: University of Nebraska Press.

Tjaden, P. and N. Thoennes. 2006. Extent, Nature and Consequences of Rape Victimization: Findings from the National Violence against Women Survey. Washington, DC: National Institute of Justice, Report NC] 210346.

US Bureau of Justice Statistics. 2005. Criminal Victimization in the United States. Washington, DC: National Justice Statistics, Publication \# 215244.

Weber, S. 1999. "Family Scenes: Some Preliminary Remarks on Domesticity and Theatricality." The South Atlantic Quarterly 98(3): 355-66.

\section{About the Author}

Sameena Mulla is Assistant Professor in the Department of Social and Cultural Sciences at Marquette University where she teaches anthropology. She is currently working on a book focusing on the intertwined nature of therapeutic and juridical institutions in sexual assault interventions in Baltimore, Maryland, based on three and a half years of field research in an emergency room forensic nursing program. Her next project examines the

Home Cultures, Vol. 5, No. 3 (November 2008): pg. 301-325. DOI. This article is (C) Bloomsbury Publishing and permission has been granted for this version to appear in e-Publications@Marquette. Bloomsbury Publishing does not grant permission for this article to be further copied/distributed or hosted elsewhere without the express permission from Bloomsbury Publishing. 
NOT THE PUBLISHED VERSION; this is the author's final, peer-reviewed manuscript. The published version may be accessed by following the link in the citation at the bottom of the page.

way that laboratory science shapes the unfolding of the experience of sexual assault intervention.

Home Cultures, Vol. 5, No. 3 (November 2008): pg. 301-325. DOI. This article is @ Bloomsbury Publishing and permission has been granted for this version to appear in e-Publications@Marquette. Bloomsbury Publishing does not grant permission for this article to be further copied/distributed or hosted elsewhere without the express permission from Bloomsbury Publishing. 